Journal of Engineering and Applied Sciences 15 (6): 1502-1507, 2020

ISSN: 1816-949X

(C) Medwell Journals, 2020

\title{
Premixed Combustion Characteristics Between Biosolar That Producted Pertamina with Biodiesel from Coconut Waste (Cocos Nucifera)
}

\author{
S. Digdo Listyadi, Nasrul Ilminafik, Hary Sutjahjono, D. Tri Vicca and Salman Al Farisi \\ Department of Mechanical Engineering, Faculty of Engineering, \\ University of Jember, Jember, Indonesia
}

\begin{abstract}
Biodiesel can be an alternative fuel in Indonesia and can be made from various ingredients. Waste coconut is one of the ingredients that biodiesel can make because it still contains oil around $15-24 \%$ of its weight. This study was conducted to determine the characteristics of burning biodiesel from waste coconut. Burning is carried out premixed using a bunsen burner $\mathrm{mm}$ at the equivalent ratio of $0.8 ; 1$ and 1 . 2. The fuel used is biosolar that producted of PT Pertamina Indonesia mixed with biodiesel from waste coconut with variations in the composition of 0 (B0), 10\% (B10), 20\% (B20), 30\% (B30) and 100\% (B100). The flame on the bunser burner is measured it's the flame temperature and taken photographed to obtain the flame height and combustion speed. The results showed that the addition of this type of biosiesel to biosolar lowered the flame temperature because the biodiesel heating value was lower than the biosolar of Pertamina products. This was proven that the decrease in flame temperature caused the flame height to increase and the combustion speed decreased, so that, the biodiesel evaporation process took longer than the biosolar produced by Pertamina.
\end{abstract}

Key words: Biodiesel from cocos nucifera, premixed combustion, temperature, biodiesel, products

\section{INTRODUCTION}

Indonesia is a tropical country where many plants in this country contain vegetable oils, one of which is coconut (Mardiatmoko and Ariyanti, 2018). Coconut production in Indonesia is one of the largest in the world with a production of 18.30 million tons per year (Mardiatmoko and Ariyanti, 2018). Every $1 \mathrm{~kg}$ of grated coconut meat can produce $190 \mathrm{~g}$ of coconut pulp (Farizaldi, 2016) and coconut pulp still contains coconut oil around $15-24 \%$ of the weight of coconut pulp (Sulaiman et al., 2013), so that, the potential of coconut pulp to be made into biodiesel is very large.

The results of the study of making coconut pulp biodiesel by transesterification conducted by Maurina et al. include density, viscosity, acid value in accordance with SNI 7182-2012. The examination of the characteristics of biodiesel from coconut pulp by Sulaiman et al. (2013) includes the density, viscosity, acid value, cloud point according to ASTM Standards D6751 and EN 14214. Not only the characteristic testing of biodiesel can be analyzed but testing the characteristics of combustion is also a topic that needs to be investigated. Several studies on biodiesel from coconut ingredients have been carried out such as Bello et al. (2016), Putri and Supranto (2012) and others. However, research on burning coconut oil biodiesel is mostly done in diesel engines such as Hossain et al. (2012), Kalam (2003) and Pereira et al. (2014) and others. The research on premixed biodiesel combustion with coconut oil ingredients is still small. Malik et al. (2017) conducted research in a liquid fuel burner and Wirawan et al. (2013) research conducts on perforated burner while the measured parameters are temperature, flame, combustion speed.

Testing the characteristics of premixed combustion in vegetable oils using bunsen burner conducted by Muhaya et al. (2015) shows that coconut oil has the highest speed of flame compared to kapok seed oil and jatropha oil. The combustion speed shows that the flame angle of the combustion results is directly proportional to the combustion speed. In addition, premixed biodiesel combustion affects the combustion speed and the flame height where the combustion speed is inversely proportional to the equivalent ratio and the height of flame is directly proportional to the equivalent ratio. The height of the combustion flame indicates that the fuel reacts with air at the closest end of the nozzle (Wirawan et al., 2013).

The examination of the combustion characteristics of coconut oil biodiesel is also carried out in the hele-shaw cell type combustion chamber. The study stated that glycerol can affect combustion because the eqiuvalence ratio of 1.23 glycerol can absorb water vapor which causes many micro explosions (Patel et al., 2016). 
Coconut oil biodiesel is also called Coconut Methyl Ester (CME). The research on CME combustion was carried out by Malik et al., (2017), this was done to find out the combustion characteristics such as exhaust gas emissions and the flame temperature from the mixing of CME with diesel oil with the equality ratio used was $0.8 ; 1$ and 1,2. The test results show that the addition of CME can reduce the temperature of the flame. Combustion flame temperatures increase with increasing equivalence ratios from 0.8-1.2.

Based on these reasons, research is needed to determine the characteristics of premixed combustion in biodiesel by adding coconut pulp oil biodiesel characteristics which include flame temperature, flame height and flame combustion rate with an equivalent ratio of 0.8 .

\section{MATERIALS AND METHODS}

The research was conducted with 2 testing stages, namely testing the characteristics of biodiesel and testing the characteristics of combustion. Testing the characteristics of biodiesel is done to measure 4 parameters, namely density, viscosity, flash point and calorific value. Calorific value testing uses bomb calorymeter (Brand: PAAR $1241 \mathrm{EF}, 220 \mathrm{~V}, 50 \mathrm{~Hz}$ ) and flash point testing using flash point tester (Leoybold Brand, $220 \mathrm{~V}, 50 / 60 \mathrm{~Hz}, 420 \mathrm{~W}$, 1987). The characteristic test results will be analyzed for the suitability of permitted biodiesel standards (SNI 7182: 2015). In testing combustion characteristics, biosolar used is biosolar produced by PT Pertamina Indonesia. The premixed combustion test using bunsen burner with the installation scheme of the tool is shown in Fig.1.

Variations in fuel composition include B0 (100\% biosolar), B10 (90\% biosolar and 10\% biodiesel), B20 (80\% biosolar and 20\% biodiesel) and B30 (70\% biosolar and 30\% biodiesel) and B100 (100\% biodiesel) with equality ratio $(\varphi) 0.8 ; 1$ and 1.2 for each variation of fuel. Fuel flow discharge is set at $0.85 \mathrm{mLmin}^{-1}$. Air discharge is adjusted by calculation $\varphi$.

Fuel B0, B10, B20, B30 and B100 are flowed into the copper pipe using a syringe pump. The heater in the copper pipe fuel line and mixing chamber is maintained at $200^{\circ} \mathrm{C}$. The ignition is done when the smoke is out of the bunsen burner. The flame temperature gauge is done using thermocouple type K. Visual photo taking is done by recording the flame using a Canon E50 Kiss X7 camera (18 Megapixel sensor; 4 continuous shooting 60 frames per second; shutter speed $30-1 / 4000$ sec with a resolution of 1920x1080). The video recording of the flame is then used as an image with 60 frames/sec and the image selection is taken on a stable flame to be able to measure the fire height and fire angle from the results of image selection using Image-J Software. Data collection

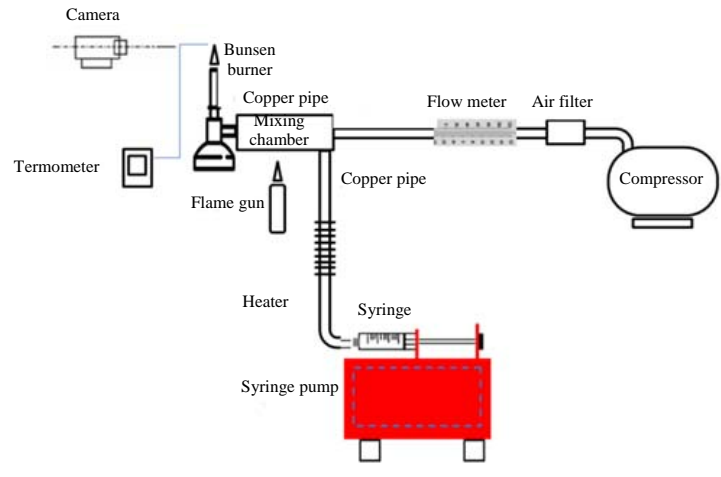

Fig. 1: Scematic of a testing tool

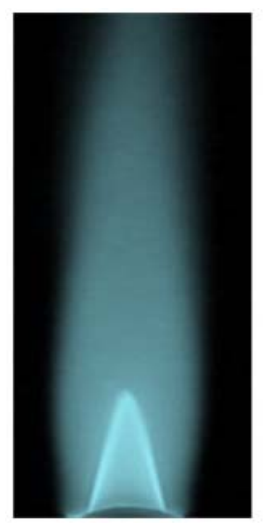

Fig. 2: Point of measurement of flame temperature

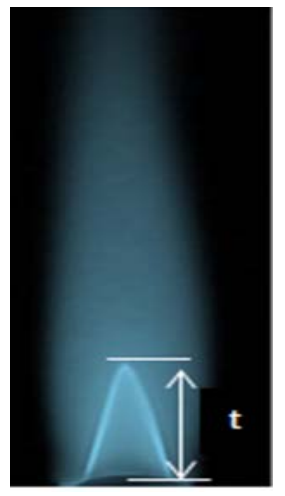

Fig. 3: Measurement of flame height

at temperature is carried out in the inner cone or premixed region as shown in Fig. 2. Data on the flame height is shown in Fig. 3.

\section{RESULTS AND DISCUSSION}

The characteristics of coconut pulp oil biodiesel used in this study are in accordance with SNI 7182: 2015 Standards (Table 1). 
Table 1: Results of testing the characteristics of coconut pulp oil biodiesel

\begin{tabular}{|c|c|c|c|}
\hline \multirow{2}{*}{$\begin{array}{l}\text { B100 biodiesel } \\
\text { test parameters }\end{array}$} & \multicolumn{2}{|l|}{ Fuel } & \multirow{2}{*}{$\begin{array}{l}\text { SNI 7182:2015 } \\
\text { (Biodiesel) }\end{array}$} \\
\hline & Biodiesel & Biosolar & \\
\hline Density $15^{\circ} \mathrm{C}\left(\mathrm{g} \mathrm{mL}^{-1}\right)$ & 0.881 & $0.815-0,860$ & $850-890$ \\
\hline Viscosity $40^{\circ} \mathrm{C}$ (cst) & 5.191 & $2-4.5$ & 2. 3- 6.0 \\
\hline Calorific value $\left(\mathrm{cal} \mathrm{g}^{-1}\right)$ & 9319.55 & 10602. 221 & - \\
\hline Flash point $\left({ }^{\circ} \mathrm{C}\right)$ & 123 & 52 & Min 100 \\
\hline
\end{tabular}

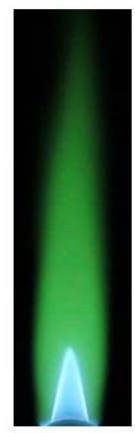

B0

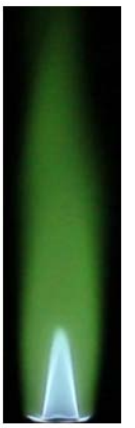

B10

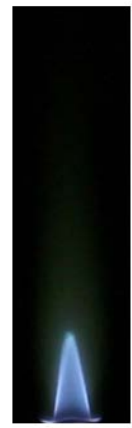

B20

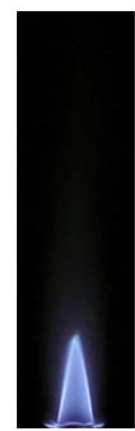

B30

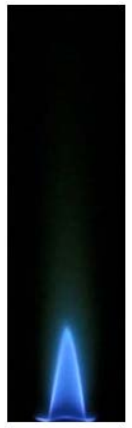

B100

Fig. 4: Flame equivalent ratio of 0.8

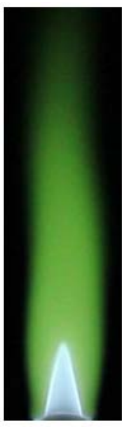

B0

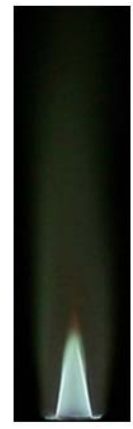

B10

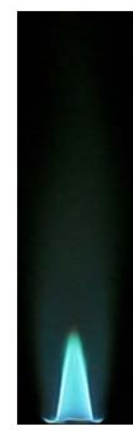

B20

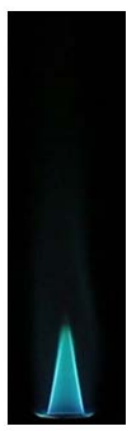

B30

Fig. 5: Flame equivalent ratio of 1

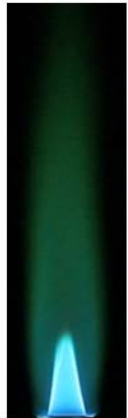

B0

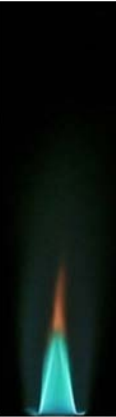

B10

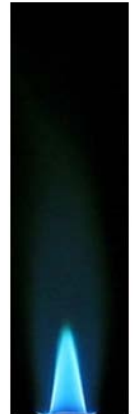

B20

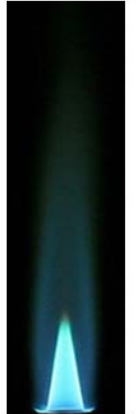

B30

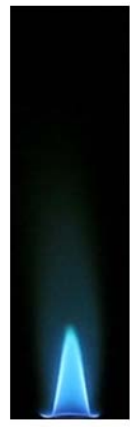

B100
Fig. 6: Flame equivalent ratio of 1.2

The flame: The results of the combustion flame can be seen in Fig. 4 until Fig. 6. Figure 4-6 shows a picture of premixed combustion flame with a mixture composition of B0, B10, B20, B30, B100 and the equivalent ratio (Ø)

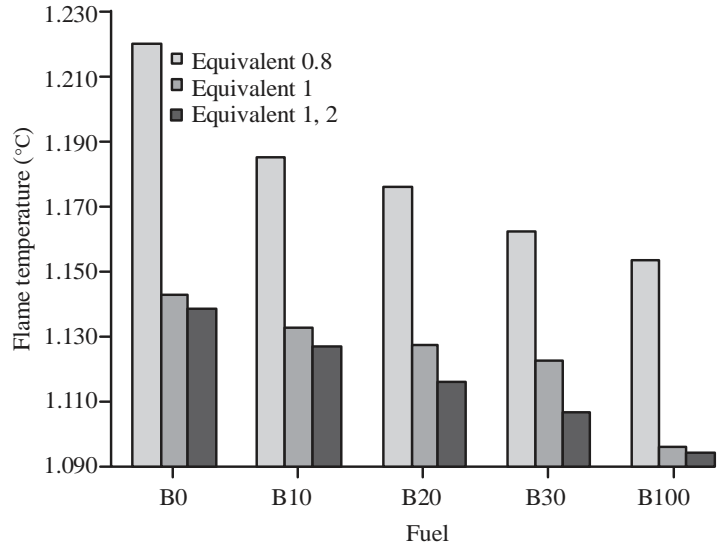

Fig. 7: Graph of flame temperature

0.8 ; 1 and 1.2. At B0 combustion the equivalent ratio 0.8 looks the flame is green in the diffusion combustion area as well as at $\mathrm{B} 0$ the equivalent ratio 1 and the equivalent ratio 1.2. The green color decreases in combustion $\mathrm{B} 0$ from the equivalent ratio 0.8 to equivalent ratio 1.2. In combustion B10 equivalent ratio 0.8 there is a green color in the diffusion combustion area, this shows a decrease in green color when the biodiesel composition is greater. This green color is caused by chemical elements or atomic atoms in copper pipes evaporating and burning in biodiesel, so that, the green color is only found in combustion with a larger biosolar composition (Amajama, 2016).

In B10 combustion with equivalent ratio 1.2 there is a red color in the diffusion combustion area whereas in the equivalent ratio 0.8 and equivalent ratio 1 there is no red color in the diffusion combustion area. The red flame color is due to the composition of biodiesel and biodiesel has a fairly large mixture ratio of 1:9 and only occurs when the ratio is equivalent to 1.2 .

The flame temperature: The results of the flame temperature test are shown in Fig. 7. Figure 7 is a graph of the test results of the combustion flame temperature of biodiesel mixtures and biodiesel with variations in the ratio equivalents. The highest flame temperature in combustion B0 with an equivalent ratio of 0.8 is $1220^{\circ} \mathrm{C}$ and the lowest flame temperature in combustion B100 is equivalent to a ratio of 1.2 of $1094^{\circ} \mathrm{C}$. These results indicate that the greater the content of biodiesel in the fuel mixture the lower the flame temperature. The flame temperature from combustion results is influenced by the heating value contained in the fuel, the greater the heating value of the fuel, the higher the flame temperature of the combustion (Malik et al., 2017). Biosolar heating value is greater $(10,602.2$ calories/g) than biodiesel heating value (9319.55 calories/g), so that, the addition of biodiesel to the fuel mixture causes the flame temperature to be low. 


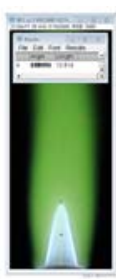

B0

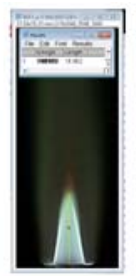

B10

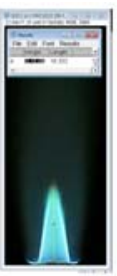

B20

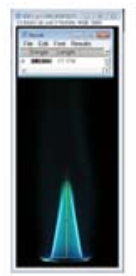

B30

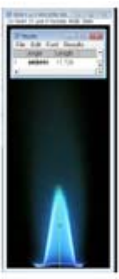

B100
Fig. 8: Measurement of flame height at equivalent ratio 1

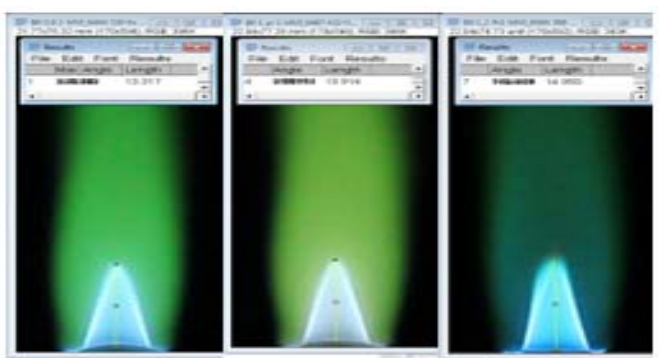

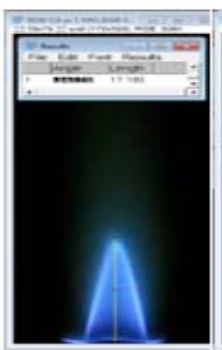

0.8

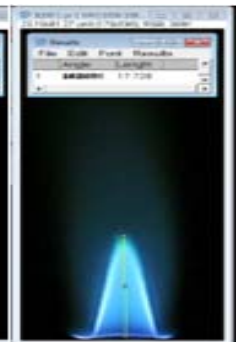

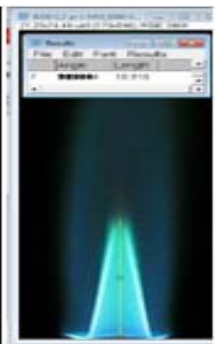

1.2
Fig. 9(a, b): (a) High pure biosolar flame (B0) and (b) High fire pure coconut waste biodiesel (B100)

The flame height: The results of high combustion flame testing using the help of Image J Software. The results of measurements of flame height with variations in the composition of biosolar mixtures with biodiesel are shown in Fig. 8 and the results of measurements of flame height with variations in equivalent values are shown in Fig. 9.

From Fig. 8 and 9, there is a difference in the height of flame in each variation. Furthermore, the results of measurements of flame height are shown in Table 2 and are displayed in graphical form (Fig. 10).

Figure 10 is a graph of the results of a high-test combustion flame of biosolar and biodiesel blends with variations in the ratio equivalents. The highest value of the lowest fire in combustion B0 with an equivalent ratio of 0.8 is $13.343 \mathrm{~mm}$. The highest flame value is highest in B100 combustion with an equivalent ratio of 0.8 of $18.633 \mathrm{~mm}$. These results indicate the greater the content of biodiesel in the fuel mixture, the higher the fire increases.

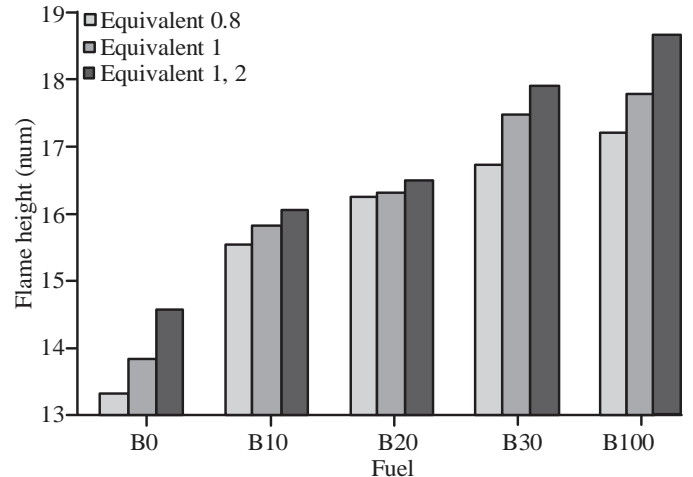

Fig. 10: Graph of flame height

The mechanism of combustion from liquid fuel is that fuel can burn after passing through the evaporation phase. The fuel vapor will diffuse with the oxidizer to form reactants, then the fuel will burn. Biosolar has a lower evaporation temperature compared to biodiesel, so that, the biodiesel evaporation process takes longer than biosolar. This causes the biodiesel burning flame at the bunsen burner end to be higher than the biosolar combustion flame (Muhaya et al., 2015). From the data of fire height measurement shows that the ratio ratio 0.8 has a fire height lower than the fire height equivalent ratio 1.2. This is due to the large equivalent value $(\varnothing>1)$, the air is more than the fuel, so that, air and fuel diffuse more quickly than compared to the equivalent value of the low ratio $(\varnothing<1)$ (Sasongko, 2018).

The speed of combustion: Testing the speed of combustion is done with the help of a camera to take pictures of flames. Shooting is used to determine the angle of flame angle. The flame angle is used to find the speed of combustion by calculation. Photos used for speed measurement are like Fig. 9 and 10. Calculation of combustion speed using Eq. 1:

$$
\mathrm{S}_{\mathrm{L}}=\mathrm{Vu} \sin \alpha
$$

Where:

$\mathrm{S}_{\mathrm{L}}$ : Burning speed $\left(\mathrm{cmsec}^{-1}\right)$

$\mathrm{Vu}$ : Reactant speed $\left(\mathrm{cmsec}^{-1}\right)$

$\alpha \quad$ : Fire angle $\left(^{\circ}\right)$

To calculate Vu, Eq. 2 is used:

$$
\mathrm{Vu}=\frac{\text { Qair.Qfuel }}{\mathrm{A}}
$$

Where:

$\mathrm{Vu} \quad$ : Reactant speed $\left(\mathrm{cmsec}^{-1}\right)$

Qfuel : Fuel discharge $\left(\mathrm{mLsec}^{-1}\right)$

Qair : Air discharge $\left(\mathrm{mLsec}^{-1}\right)$

A : Bunsen burner surface Area $\left(\mathrm{cm}^{2}\right)$ 
J. Eng. Applied Sci., 15 (6): 1502-1507, 2020

\begin{tabular}{|c|c|c|c|c|}
\hline Fuel & Equivalent ratio & Average angle of fire $\left(^{\circ}\right)$ & Reactant speed Vu $\left(\mathrm{cmsec}^{-1}\right)$ & SL burning speed $\left(\mathrm{cmsec}^{-1}\right)$ \\
\hline \multirow[t]{3}{*}{$\overline{\mathrm{B} 0}$} & 0.8 & 14.94 & 66.5 & 17.142 \\
\hline & 1.0 & 13.83 & 53.2 & 12.715 \\
\hline & 1.2 & 13.94 & 44.34 & 10.682 \\
\hline \multirow[t]{3}{*}{ B10 } & 0.8 & 13.69 & 65.97 & 15.617 \\
\hline & 1.0 & 13.05 & 52.78 & 11.919 \\
\hline & 1.2 & 12.65 & 43.99 & 9.636 \\
\hline \multirow[t]{3}{*}{ B20 } & 0.8 & 12.90 & 65.14 & 14.540 \\
\hline & 1.0 & 11.91 & 52.11 & 10.752 \\
\hline & 1.2 & 11.65 & 43.43 & 8.772 \\
\hline \multirow[t]{3}{*}{ B30 } & 0.8 & 11.89 & 64.52 & 13.292 \\
\hline & 1.0 & 11.23 & 51.62 & 10.049 \\
\hline & 1.2 & 10.74 & 43.02 & 8.016 \\
\hline \multirow[t]{3}{*}{ B100 } & 0.8 & 11.09 & 57.86 & 11.133 \\
\hline & 1.0 & 10.69 & 46.29 & 8.587 \\
\hline & 1.2 & 9.970 & 38.58 & 6.679 \\
\hline
\end{tabular}

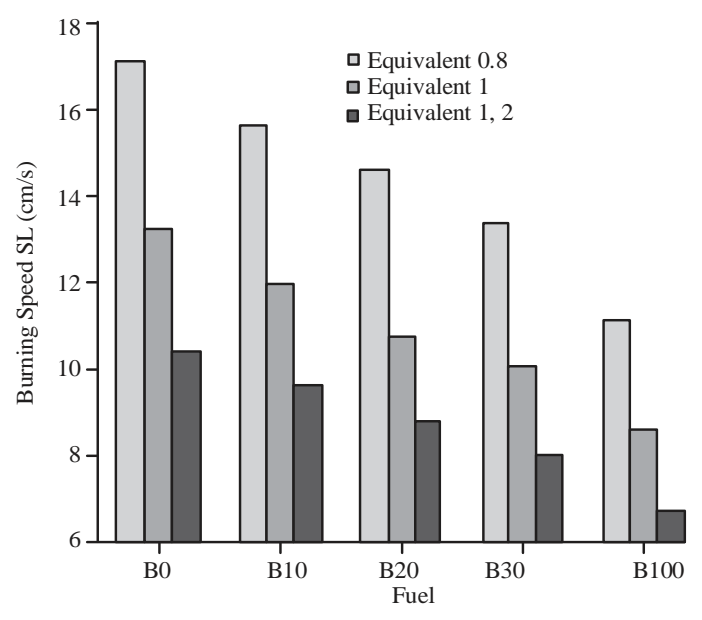

Fig. 11: Burning speed graph

This study uses a bunsen burner with a surface area of $0.3846 \mathrm{~cm}^{2}$. The result of combustion speed is shown in Table 2 and displayed in graphical form in Fig. 11.

Figure 11 shows a graph of the combustion velocity of biodiesel and biosolar mixture in the variation of the equivalent ratio. The greatest value of combustion velocity occurs in B0 fuel with an equivalent ratio of 0.8 which is equal to $17.124 \mathrm{cmsec}^{-1}$. The smallest combustion velocity value occurs in B100 fuel with an equivalent ratio of 1.2 which is equal to $6.679 \mathrm{cmsec}^{-1}$. Based on the graph above shows that the greater the biodiesel content in the fuel mixture (biosolar with biodiesel), the smaller the value of the combustion speed. The value of the combustion speed is influenced by the flash point value. At the flash point temperature, the fuel will evaporate and mix with air in the mixing chamber to form a reactant which can then ignite. This shows that the higher the flash point value of a fuel, the more fuel it becomes difficult to burn (Riwu et al., 2016). The flash point value of coconut pulp biodiesel is higher $\left(123^{\circ} \mathrm{C}\right)$ than the flash point biosolar value $\left(52^{\circ} \mathrm{C}\right)$, so that, the more biodiesel content in the fuel mixture results in decreasing the combustion rate of the fuel mixture.
In addition, to flash points, the value of fuel density can also affect the speed of combustion. The greater the density value in the fuel, the weaker the ability of the fuel to be atomized. Biodiesel coconut pulp has a greater density and viscosity than biodiesel, so that, the speed of burning biodiesel is lower than biosolar (El-Araby et al., 2018).

\section{CONCLUSION}

Testing the characteristics of premixed combustion in biosolar by mixing coconut waste biodiesel can be summarized as follows: the flame temperature will decrease from composition B0 to B100 when there is an increase in the amount of biodiesel in the mixture. Decreased temperature caused because the heating value of biodiesel is smaller than biosolar. Whereas when the equivalent value ratio is increased from 0.8 to the equivalent ratio of 1.2 , the flame temperature will decrease. Decreasing the temperature occurs because the equivalent value of a higher ratio will cause the fuel mixture to become richer.

The flame height increases from the composition B0 to B100 when there is an increase in the amount of biodiesel in the mixed composition then. This increase is due to the lower biosolar evaporation temperature than the biodiesel evaporation temperature. Whereas when the equivalent ratio is increased from 0.8 to the equivalent ratio of 1.2, the fire height will increase. This increase occurs because the greater the equivalent ratio will make the fuel mixture richer.

The combustion speed tends to decrease from the composition B0 to B100. This decrease is due to the flash point value and biodiesel density greater than the flash point and biosolar density at the same time when the equivalent ratio is increased from 0.8 to equivalent ratio 1.2 , the combustion speed decreases. The decrease occurs because the ratio of equivalents increases causing the mixture of fuel to become richer. 


\section{SUGGESTION}

Suggestions that can be submitted for further research are the use of heaters that produce higher temperatures and can be controlled as needed and testing on various AFR variations.

\section{REFERENCES}

Amajama, J., 2016. A proposed concept about stars: The energy creation, color and formation. J. Sci. Eng. Res., 3: 55-63.

Bello, E.I., I.T. Adekanbi and F.O. Akinbode, 2016. Production and characterization of coconut (Cocos nucifera) oil and its methyl ester. Eur. J. Pure Applied Chem., 3: 38-48.

El-Araby, R., A. Amin, A.K. El Morsi, N.N. El-Ibiari and G.I. El-Diwani, 2018. Study on the characteristics of palm oil-biodiesel-diesel fuel blend. Egypt. J. Pet., 27: 187-194.

Farizaldi, 2016. [Evaluation of coconut Ampas nutrition containers with fermentation with local years and long different fermentations (In Indonesian)]. Jambi Univ. Res. J. Sci. Ser., 18: 49-55.

Hossain, S.M.C., Y. Rekhu, K.S. Faraz and M.U. Islam, 2012. Biodiesel from coconut oil: A renewable alternative fuel for diesel engine. World Acad. Sci. Eng. Technol., 68: 1289-1293.

Kalam, M.A., M. Husnawan and H.H. Masjuki, 2003. Exhaust emission and combustion evaluation of coconut oil-powered indirect injection diesel engine. Renewable Energy, 28: 2405-2415.

Malik, M.A., A. Shaiful, M.M. Jaafar and M.A. Sahar, 2017. Combustion and emission characteristics of coconut-based biodiesel in a liquid fuel burner. Energies, Vol. 10, No. 4. 10.3390/en10040458.
Mardiatmoko, G. and M. Ariyanti, 2018. [Production of Coconut Plants (Cocos nucifera L.)]. Badan Penerbit Fakultas Pertanian Universitas, Kota Ambon, Indonesia, Pages: 187 (In Indonesian).

Muhaya, S.B.L, I.N.G. Wardana and D. Widhiyanuriyawan, 2015. [Combustion of premixed vegetable oil in Bunsen burner type (In Indonesian)]. Mech. Eng. J., 6: 45-50.

Patel, C., S. Lee, N. Tiwari, A.K. Agarwal, C.S. Lee and S. Park, 2016. Spray characterization, combustion, noise and vibrations investigations of Jatropha biodiesel fuelled genset engine. Fuel, 185: 410-420.

Pereira, R.G., O.E.P. Tulcan, C.E. Fellows, I.M. Da Silva, D.M.D.E.S. Filho, V. De Jesus Lameira and O.L.G. Quelhas, 2014. Energy generation using coconut biodiesel and coconut oil in a stationary engine. Int. J. Oil Gas Coal Technol., 7: 450-473.

Putri, S.K. and S.R. Supranto, 2012. [Study of the process of making biodiesel from coconut oil (coconut oil) with the help of ultrasonic waves (In Indonesian)]. J. Process Eng., 6: 20-25.

Riwu, D.B.N., I.N.G. Wardana and L. Yuliati, 2016. Premixed burning coconut oil in perforated burners. J. Mech. Eng., 7: 41-47.

Sasongko, M.N., 2018. [The influence of the percentage of used cooking oil against characteristics burning biodiesel droplets (In Indonesian)]. Flywheel J. Mech. Eng. Untirta, 4: 8-13.

Sulaiman, S., A.R.A. Aziz and M.K. Aroua, 2013. Optimization and modeling of extraction of solid coconut waste oil. J. Food Eng., 114: 228-234.

Wirawan, I.K.G., I.N.G. Wardana, R. Soenoko and S. Wahyudi, 2013. Premixed combustion of coconut oil on perforated burner. Int. J. Renewable Energy Dev., 2: 133-139. 